\title{
Isolation and characterization of a reserve protein from the seeds of Opuntia ficus-indica (Cactaceae)
}

A.F. Uchoa, P.A.S. Souza,

R.M.L. Zarate, E. Gomes-Filho and F.A.P. Campos
Departamento de Bioquímica e Biologia Molecular, Universidade Federal do Ceará, Fortaleza, CE, Brasil

\section{Correspondence \\ F.A.P. Campos \\ Departamento de Bioquímica e \\ Biologia Molecular, UFCE \\ Caixa Postal 1065 \\ 60001-970 Fortaleza, CE \\ Brasil \\ Fax: 55 (085) 288-9829 \\ E-mail: bioplant@ufc.br. \\ Research supported by CNPq (No. 520332/93-8).}

Received September 29, 1997 Accepted March 18, 1998

\section{Abstract}

We describe here the isolation and characterization of a major albumin from the seeds of Opuntia ficus-indica (Cactaceae). This protein has a molecular mass of $6.5 \mathrm{kDa}$ and was isolated by a combination of gel filtration chromatography and reverse-phase HPLC. The amino acid composition of this protein was determined and it was shown to have similarities with the amino acid composition of several proteins from the $2 \mathrm{~S}$ albumin storage protein family. The $\mathrm{N}$-terminal amino acid
Key words

- Cactaceae

- Prickly-pear

- Opuntia ficus-indica

- Seed proteins

- 2S albumins

\section{Introduction}

Over the years the prickly-pear (Opuntia ficus-indica) has shown its usefulness as a forage crop for small farmers in the Brazilian northeast. This is especially true in the years of drought, when on many occasions its fleshy phylloclads are the sole source of water and nutrients for farm animals $(1,2)$. The new biotechnological tools are opening new opportunities for manipulating important agronomic traits of different crops. In our laboratory we are interested in exploring the possibility of using these tools to improve the nutritional quality of the pricklypear for farm animals. Specifically, we want to introduce in it a transgene coding for a protein of good nutritional quality and to have this transgene expressed at high levels in the phylloclads. In order to achieve this we are developing protocols for plant regeneration and transformation and we are studying the pattern of protein deposition in seeds and phylloclads. We present here data on the isolation and characterization of the major salt-soluble protein from the seeds and demonstrate that this protein belongs to the $2 \mathrm{~S}$ albumin storage protein family. To our knowledge, this is the first report on the characterization of a seed reserve protein from a Cactaceae plant.

\section{Material and Methods}

\section{Plant material}

Seeds of $O$. ficus-indica cv. Gigante were obtained from mature fresh fruits collected in May 1996 on a farm in Madalena, Ceará, Brazil.

\section{Protein extraction and purification}

Salt-soluble proteins were extracted from seed flour in $0.1 \mathrm{M}$ Tris $/ \mathrm{HCl}$ and $0.5 \mathrm{M}$ $\mathrm{NaCl}, \mathrm{pH} 8.0$, for $2 \mathrm{~h}$. After centrifugation (10000 $\mathrm{g}, 20 \mathrm{~min}, 4^{\circ} \mathrm{C}$ ), ammonium sulfate was added to the supernatant to a concentra- 
tion of $90 \%$ and the precipitated proteins were recovered by centrifugation. After dialysis against distilled water at $4{ }^{\circ} \mathrm{C}$ and centrifugation, the albumin and globulin fractions were obtained. The albumins were fractionated on a Sephacryl S-100-HR column $(80 \times 2.6 \mathrm{~cm})$ equilibrated and eluted with 50 $\mathrm{mM}$ ammonium bicarbonate at a flow rate of $30 \mathrm{ml} / \mathrm{h}$ and $4.3-\mathrm{ml}$ fractions were collected. This column was previously calibrated using the MW-GF-70 kit for molecular mass 6.5 to $66 \mathrm{kDa}$ from Sigma Chemical CO. (St. Louis, $\mathrm{MO})$. The effluents containing the $6.5-\mathrm{kDa}$ protein as demonstrated by SDS-PAGE were pooled, freeze-dried and fractionated by molecular exclusion HPLC on a Superdex Peptide HR 10/30 column from Pharmacia Biotech (Uppsala, Sweden), developed with an HPLC system from Waters Corporation (Millford, MA). The column was equilibrated and eluted with $50 \mathrm{mM}$ ammonium bicarbonate, at a flow rate of $0.5 \mathrm{ml} / \mathrm{min}$. A single protein peak was obtained which was further fractionated by reverse phase-HPLC (RPHPLC) on a 3.9 x 300-mm $\mu$-Bondapak C-18 column (Waters) linked to an HPLC system from Waters Corporation. The column was equilibrated with $0.1 \%$ trifluoracetic acid and proteins were eluted with a linear gradient of $0-60 \%$ acetonitrile in $0.1 \%$ trifluoracetic acid, run in $60 \mathrm{~min}$. The effluents were monitored at $280 \mathrm{~nm}$ in all chromatographic steps. Protein concentration was determined

Figure 1 - Chromatography of the crude albumin fraction from $O$. ficus-indica seeds on a Sephacryl S-100-HR column. Proteins $(60 \mathrm{mg}$ in $4.0 \mathrm{ml}$ of running buffer) were eluted with 50 $\mathrm{mM}$ ammonium bicarbonate at a flow rate of $30 \mathrm{ml} / \mathrm{h}$ and samples of $4.2 \mathrm{ml}$ were collected. The fractions indicated by the horizontal bar were pooled and subjected to the next purification step.

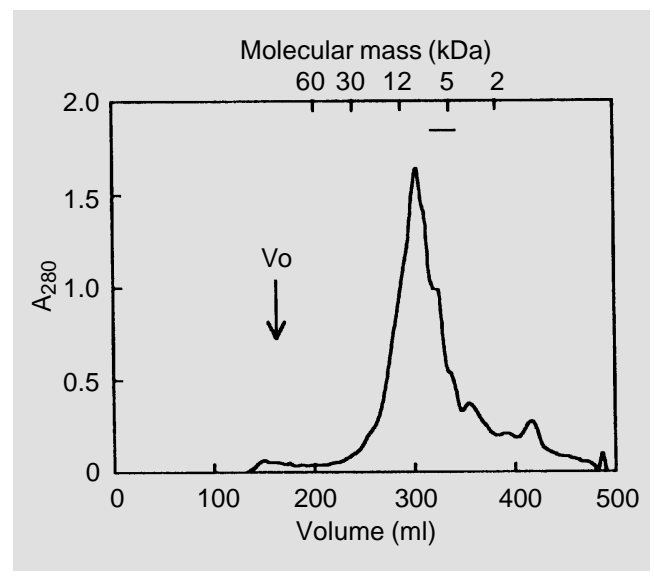

by the protein-dye binding method of Bradford (3).

\section{Amino acid analysis}

Protein samples were resuspended in 500 $\mu \mathrm{l}$ of constant-boiling $6 \mathrm{~N} \mathrm{HCl}$ containing $0.1 \%$ phenol. Ten percent of each sample was brought up to a final volume of $150 \mu$ of constant-boiling $\mathrm{HCl}(6 \mathrm{~N})$ plus $0.1 \%$ phenol. Hydrolysis was carried out in evacuated, sealed, thick-walled borosilicate glass tubes for $24 \mathrm{~h}$ at $120^{\circ} \mathrm{C}$. Cooled tubes were opened and samples were dried under vacuum and stored at $-20^{\circ} \mathrm{C}$ until derivatization. Samples were derivatized with phenylisothiocynate (PITC) (Pierce, Millford, IL) by the method of Bidlingmeyer et al. (4). The protein hydrolysates were redried twice with ethanol:water: triethylamine $(2: 2: 1, \mathrm{v} / \mathrm{v})$, and derivatized with ethanol:water: triethylamine: PITC (7:2:2:1, v/v). Samples were analyzed by RP-HPLC on a Waters system equipped with a Waters 712 WISP and a Waters system interface module linking the HPLC to a Baseline 810 workstation. A Pico-Tag column for amino acid hydrolysate analysis (Waters) maintained at $46^{\circ} \mathrm{C}$ by a Waters temperature-control module was used in accordance with the manufacturer's recommended procedure. Hydrolysate amino acid standards (Sigma) were used for peak identification and subsequent calculations. Lysozyme was also analyzed and the results were compared with published values to ensure the accuracy of the technique. Three independent determinations were performed for each sample. Selected replicates were analyzed in duplicate to ensure repeatability.

\section{SDS-PAGE}

Gel electrophoresis was performed using the tricine-SDS polyacrylamide gel electrophoresis method for the separation of low molecular mass proteins described by Schagger and Jagow (5). The proteins con- 


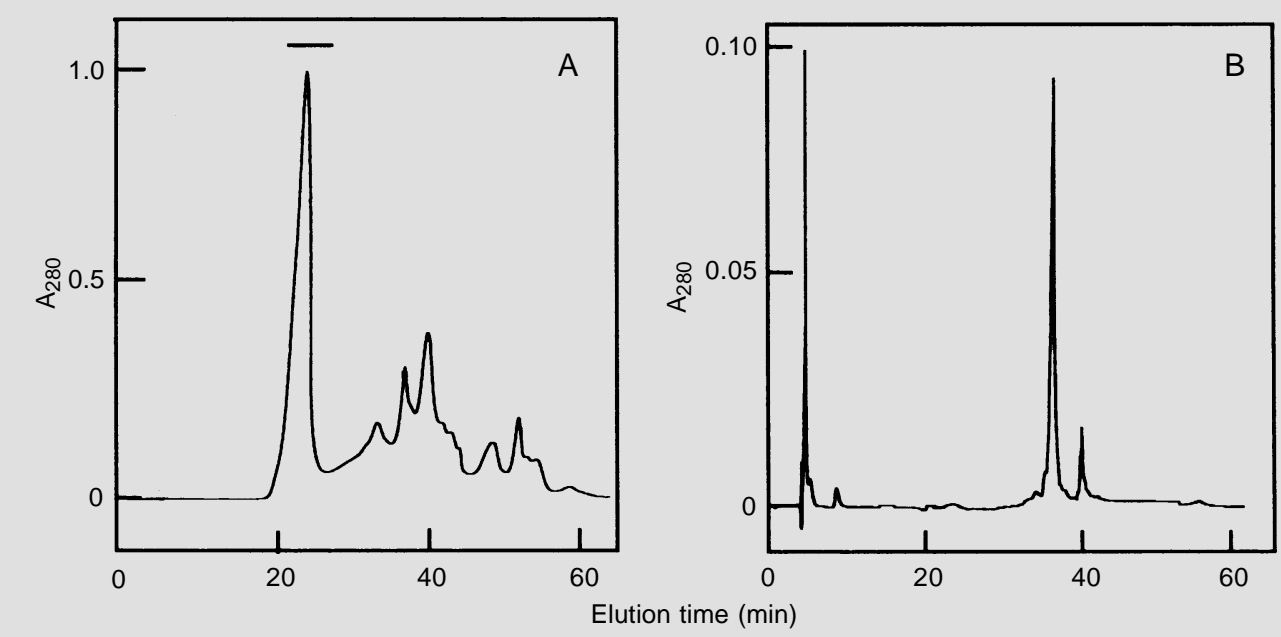

tained in the MW-SDS-17S kit (Sigma) for molecular mass 3.46 to $16.95 \mathrm{kDa}$ were used as molecular mass markers.

\section{$\mathrm{N}$-Terminal analysis}

The homogeneity of the purified protein and the N-terminal sequence were determined by the DABITC/PITC double-coupling method (6) following the protocol described by Campos and Richardson (7).

\section{Results and Discussion}

Chromatography of the albumin fraction on a Sephacryl S-100-HR column yielded a major broad protein peak eluting in the molecular mass range of 20 to $5 \mathrm{kDa}$ (Figure 1). The protein profile of every third tube was analyzed by SDS-PAGE (data not shown) and those tubes containing the $6.5-\mathrm{kDa}$ protein at high concentrations were pooled, freeze-dried and applied to a Superdex Peptide column equilibrated and eluted with 50 $\mathrm{mM}$ ammonium bicarbonate. This yielded a major peak containing the $6.5-\mathrm{kDa}$ protein eluted from 21 to $26 \mathrm{~min}$ (see horizontal bar) and several other peaks containing small peptides and other unidentified compounds (Figure 2A). Analysis by SDS-PAGE of the peak containing the $6.5-\mathrm{kDa}$ protein indi-
Figure 2 - $A$, Chromatography of a fraction enriched with the 6.5kDa protein on a Superdex Peptide HR 10/30 column. Proteins (1.0 $\mathrm{mg}$ in running buffer) were eluted with $50 \mathrm{mM}$ ammonium bicarbonate at a flow rate of 0.5 $\mathrm{ml} / \mathrm{min}$ and samples of $1.0 \mathrm{ml}$ were collected. The fractions indicated by the horizontal bar were pooled and subjected to the next purification step. $B$, RPHPLC of the fraction enriched with the 6.5-kDa protein on a $\mu-$ Bondapak C-18 column. Proteins $(200 \mu \mathrm{g})$ were eluted with a linear gradient of $0-60 \%$ acetonitrile in $0.1 \%$ trifluoracetic acid run for $60 \mathrm{~min}$

Figure 3 - Assessment of the homogeneity of the $6.5-\mathrm{kDa}$ protein purified from the seeds of $\mathrm{O}$. $\mathrm{fi}$ cus-indica by SDS-PAGE. Purified protein $(2 \mu \mathrm{g})$ was added to lane 2 and crude albumins $(20 \mu \mathrm{g})$ are shown in lane 1. Molecular weight markers are indicated on the left. 
Table 1 - Amino acid composition of the $6.5-\mathrm{kDa}$ protein isolated from the seeds of the pricklypear, as determined by Pico Tag technology.

Composition is reported as number of residues per mol of protein based on a molecular mass of 6500 . The values for cystein and tryptophan were not determined (nd). Number within parentheses represent the assigned integral values.

\begin{tabular}{lc}
\hline Amino acid & No. of residues \\
\hline Asx & $1.91 \pm 0.02(2)$ \\
Glx & $23.3 \pm 0.16(24)$ \\
Ser & $0.42 \pm 0.01(0)$ \\
Gly & $5.62 \pm 0.01(6)$ \\
His & $1.24 \pm 0.04(1)$ \\
Arg & $13.32 \pm 0.31(14)$ \\
Thr & $0.46 \pm 0.08(1)$ \\
Ala & $1.57 \pm 0.04(2)$ \\
Pro & $3.05 \pm 0.14(3)$ \\
Tyr & $2.40 \pm 0.21(3)$ \\
Val & $0.14 \pm 0.06(0)$ \\
Met & $0.11 \pm 0.04(0)$ \\
Ile & $1.56 \pm 0.11(2)$ \\
Leu & $2.16 \pm 0.16(2)$ \\
Phe & $1.45 \pm 0.19(2)$ \\
Lys & $0.24 \pm 0.04(0)$ \\
Trp & nd \\
Cys & nd \\
\end{tabular}

concentration of $39.3 \%$. The purity of the 6.5-kDa protein was demonstrated by SDSPAGE (Figure 3 ) and by $\mathrm{N}$-terminal analysis that yielded only aspartic acid as the Nterminal amino acid. This protein corresponds to $18 \%$ of the total salt soluble protein of the seed.

The protein obtained by the RP-HPLC step was used for amino acid analysis and protein sequencing. The amino acid composition of the protein (Table 1) showed that it is devoid of Ser, Val, Met and Lys and has a high percentage of Arg (23\%) and of Glx $(40 \%)$. The behavior of the protein in nondenaturing gels and in ion exchange media indicates that this protein is very basic (data not shown) and therefore most of the amino acids identified as Glx are probably Gln. Seed storage proteins are often rich in the amide amino acids glutamine and asparagine, but may also be rich in arginine (8). All three of these amino acids have a high nitrogen-tocarbon ratio, making them particularly suited for nitrogen storage (9). An amino acid composition search on the ExPASy world wide web server (http://www.expasy.ch/ch2d/ acompi.html) showed that the amino acid composition of the $6.5-\mathrm{kDa}$ protein has a high degree of similarity with the $2 \mathrm{~S}$ seed storage protein from Helianthus annus and with the $2 \mathrm{~S}$ albumin from the seeds of Ricinus communis. We obtained the N-terminal sequence of the protein by the DABITC/ PITC double-coupling method and found the sequence Asp-Pro-Tyr-Trp-Glu-Gln-Arg and found no matching sequences in the above cited proteins.

Only recently have the $2 \mathrm{~S}$ albumins become recognized as a major group of seed storage proteins. They are known to occur in species as diverse as oil-seed rape (Cruciferae), sunflower (Compositae), Brazil nut (Lecythidaceae) and lupin (Leguminosae) (10) and were initially defined as a group on the basis of their sedimentation coefficients $\left(\mathrm{S}_{20 \mathrm{w}}\right)$ of 2 (11). The data shown here indicate that the major albumin from the seeds of the prickly-pear belongs to the $2 \mathrm{~S}$ albumin storage protein. This $6.5-\mathrm{kDa}$ protein seems to be widespread in seeds of Cactaceae. Analysis of the protein profile in the saltsoluble fraction of various species of Cactaceae by SDS-PAGE indicated the presence of high concentrations of a $6.5-\mathrm{kDa}$ protein (data not shown). We are currently in the process of obtaining the complete amino acid sequence of the $6.5-\mathrm{kD}$ a protein and we want to explore the possibility of using this protein as a taxonomic marker for Cactaceae. 


\section{References}

1. Braga R (1976). Plantas do Nordeste, Especialmente do Ceará. Coleção Mossoroense. Vol. XLII. Escola Superior de Agricultura de Mossoró, Rio Grande do Norte, Brazil.

2. Vietmeyer $N(1986)$. Lesser-known plants of potential use in agriculture and forestry. Science, 232: 1379-1384.

3. Bradford M (1976). A rapid and sensitive method for the quantitation of microgram quantities of proteins utilizing the principle of protein-dye binding. Analytical Biochemistry, 72: 248-254.

4. Bidlingmeyer BA, Cohen SA \& Tarvin TL (1984). Rapid analysis of amino acids using pre-column derivatization. Journal of Chromatography, 33: 93-104.
5. Schagger H \& Jagow G (1987). Tricinesodium dodecyl sulfate-polyacrylamide gel electrophoresis for the separation of proteins in the range of 1 to $100 \mathrm{kDa}$. Analytical Biochemistry, 166: 368-379.

6. Chang JY, Brauer D \& Wittmann-Liebold $B$ (1978). Micro-sequence analysis of peptides and proteins using 4-NN-dimethylaminoazobenzene 4'-isothiacyanate/phenylisothiocyanate double coupling method. FEBS Letters, 93: 155-161.

7. Campos FAP \& Richardson M (1984). The complete amino acid sequence of the $\alpha$ amylase inhibitor I-2 from seeds of ragi (Indian finger millet, Eleusine coracana Gaertn.). FEBS Letters, 167: 221-225.

8. Shotwell MA \& Larkins BA (1989). The biochemistry and molecular biology of seed storage proteins. In: Marcus A (Editor), The Biochemistry of Plants. Vol. 15. Academic Press, New York, 297-345.

9. King JE \& Gifford DJ (1997). Amino acid utilization in seeds of loblolly pine during germination and early seedling growth. Plant Physiology, 113: 1125-1135.

10. Shewry PR, Napier JA \& Tatham AS (1995). Seed storage proteins: structures and biosynthesis. Plant Cell, 7: 945-956.

11. Youle RJ \& Huang AHC (1981). Occurrence of low molecular weight and high cysteine containing albumin storage proteins in oil-seeds of diverse species. American Journal of Botany, 66: 44-48. 